\title{
Test fluencji słownej semantycznej w logopedycznej diagnozie otępienia alzheimerowskiego - wybrane aspekty
}

\author{
Semantic Verbal Fluency Test in the Logopedic Diagnosis \\ of Alzheimer's Dementia - Selected Aspects
}

\author{
Słowa kluczowe: choroba Alzheimera, demencja, test fluencji słownej semantycznej, diagnoza logopedyczna \\ Keywords: Alzheimer's disease, dementia, semantic verbal fluency test, speech therapy diagnosis
}

\section{Streszczenie}

W artykule podjęto próbę wykazania przydatności testu fluencji słownej semantycznej w diagnozie logopedycznej osób ze zdiagnozowaną chorobą Alzheimera. Omówiono podstawowe pojęcia dotyczące fluencji słownej, zwłaszcza semantycznej, dokonano charakterystyki testu, opisano jego strukturę, przedstawiono procedurę badania i omówiono propozycje analizy wyników. Test jest jednym z najczęściej wykorzystywanych narzędzi do oceny m.in. zasobów leksykonu umysłowego, sposobu magazynowania wiedzy i możliwości jej przywoływania. Dostarcza wiedzy na temat jakości procesów językowych. Sposób realizacji zadań fluencji słownej (tj. liczba generowanych pojęć zgodnych z kryterium, liczba klastrów i ich zasób, charakter błędów) świadczy o jakości procesów językowych, o stanie pamięci semantycznej. Trudności z aktualizacją pojęć mogą być istotnym objawem rozwijających się procesów otępiennych, zwłaszcza we wczesnym stadium AD.

\footnotetext{
* Uniwersytet Łódzki, Wydział Filologiczny, Instytut Filologii Polskiej i Logopedii, Zakład Dialektologii Polskiej i Logopedii, ul. Pomorska 171/173, 90-236 Łódź, e-mail: renata.gliwa@uni.lodz.pl, ORCID: https://orcid.org/0000-0003-2231-9197.
} 


\section{Abstract}

The article attempts to demonstrate the usefulness of the semantic verbal fluency test in speech therapy diagnosis of people diagnosed with Alzheimer's disease. The basic concepts of verbal fluency, especially semantic, were discussed, the test was characterized, its structure was described, the test procedure was presented and the proposed analysis of the results was discussed. The test is one of the most frequently used tools for assessing resources of the mental lexicon, the method of storing knowledge and the possibility of recalling it. Provides knowledge about the quality of linguistic processes. The way of carrying out verbal fluency tasks (the number of generated concepts consistent with the criterion, the number of clusters and their resources, the nature of errors) proves the quality of linguistic processes and the state of semantic memory. Difficulties with updating concepts may be a significant symptom of developing dementia processes, especially in the early stages of AD.

\section{Wprowadzenie}

Ocena procesów komunikacyjnych, w tym językowych, stanowi istotę diagnostyki logopedycznej. Jednak badając pacjenta dorosłego, dysponujemy niewielką liczbą narzędzi, za pomocą których takiej diagnostyki możemy dokonać. Oczekując na nowe, wartościowe narzędzia logopedyczne, warto sięgać po te stosowane przez innych specjalistów, dające wiele możliwości interpretacji. Przykładem takiego narzędzia może być test fluencji słownej ${ }^{1}$ (dalej TFS) [por. Pąchalska, 2007].

Test ten jest jednym z narzędzi najczęściej wykorzystywanych do oceny pamięci, zasobów leksykonu umysłowego, sposobu magazynowania wiedzy i możliwości jej przywoływania, funkcji wykonawczych, organizacji myślenia i ogólnej giętkości poznawczej oraz płynności myślenia dywergencyjnego [Pąchalska, 2007, s. 59-60; Biechowska i wsp., 2012, s. 49; Ponichtera-Kasprzykowska, Sobów, 2014, s. 179]2 . Dostarcza także wiedzy na temat jakości procesów językowych - obserwowane podczas realizacji testu trudności $z$ aktualizacją słów mogą być istotnym objawem deficytów językowych, przejawiających się na przykład w postaci anomii, peryfraz, parafazji semantycznych itd. ${ }^{3}$

\footnotetext{
1 Test ma dość ugruntowaną pozycję w diagnostyce neuropsychologicznej [por. m.in. Szepietowska, Gawda, 2011; Piskunowicz i wsp., 2013; Mosiołek, 2014; Ponichtera-Kasprzykowska, Sobów, 2014]. Na temat zastosowania TFS w diagnozie logopedycznej pisały między innymi Justyna Żulewska [2015] i Renata Gliwa [2018; 2019a; 2019b; 2020].

2 Test fluencji słownej bywa wykorzystywany zarówno do oceny funkcji wykonawczych, jak i językowych, na przykład w teście MOCA autorzy włączyli próbę fluencji słownej do oceny funkcji językowych, a ocenę funkcji wykonawczych połączyli z oceną funkcji wzrokowo-przestrzennych.

3 Test fluencji słownej służy do oceny zasobów słownika mentalnego w zakresie słów treściowych, nie ocenia zasobów słów funkcyjnych, których mechanizm wyszukiwania jest nieco inny [Berko Gleason, Bernstein Ratner, 2005, s. 28-29].
} 
W artykule wyjaśniono podstawowe pojęcia dotyczące fluencji słownej, zwłaszcza semantycznej, dokonano charakterystyki testu, opisano jego strukturę, przedstawiono procedurę badania i omówiono propozycję analizy wyników. Wskazano możliwości wykorzystania testu w diagnozie logopedycznej pacjentów z otępieniem w przebiegu choroby Alzheimera.

\section{Choroba Alzheimera}

Choroba Alzheimera ${ }^{4}$ (Alzheimer's disease - dalej AD) należy do najczęstszych przyczyn wywołujących nieodwracalne otępienie ${ }^{5}$ [por. Opala, 2003; Olszewski, 2008; Kozubski, Liberski, 2014]. Jest to choroba wiążąca się ze zmianami neurodegeneracyjnymi. Rozwija się etapami, a każdy z nich charakteryzuje się intensyfikacją zaburzeń w zakresie funkcji poznawczych, w tym językowych [por. Domagała, 2007; 2015; 2019; Domagała, Sitek, 2018], umiejętności wykonywania codziennych czynności i zachowania [Barczak, Gorzkowska, Klimowicz-Morawiec, 2012; Szczudlik, Parnowski, 2012; Armstrong, Morrow, 2014; Leszek, Trypka, 2016].

\section{Test fluencji słownej - opis narzędzia}

Test fluencji słownej to narzędzie stworzone w 1938 roku przez Louisa L. Thurstone’a (Thurstone's Word Fluency Test) ${ }^{6}$ do oceny produktywności umysłowej osób z uszkodzeniami ośrodkowego układu nerwowego. W pierwotnej wersji zadaniem badanego było wypisanie jak największej liczby słów na wskazaną literę [Pąchalska, 2007, s. 59; por. też Piskunowicz i wsp., 2013].

Druga wersja testu opracowana została w 1968 roku przez Arthura Bentona. Była ona szczególnie wartościowa, ponieważ zakładała ocenę ustnej fluencji słownej, a więc mogła być stosowana także u osób z porażeniem kończyn górnych. Kolejne lata przyniosły nowe wersje tego narzędzia ${ }^{7}$.

4 Kryteria diagnostyczne choroby Alzheimera zebrano i opracowano między innymi w publikacji George'a T. Grossberga i Sanjeeva M. Kamata [2011, s. 17-21, w polskiej redakcji Tomasza Sobowa]. Wyznaczone są przez Kryteria Międzynarodowej Statystycznej Klasyfikacji Chorób i Problemów Zdrowotnych (ICD-10), Kryteria Amerykańskiego Stowarzyszenia Psychiatrów (DSM-IV), Kryteria Narodowego Instytutu Badań Starzenia i Stowarzyszenia Alzheimerowskiego (NIA/AA), Kryteria Amerykańskiego Stowarzyszenia Psychiatrów (DSM-V).

5 Stanowi od 50\% do 70\% wszystkich zdiagnozowanych typów demencji [Kozubski, Liberski, 2014, s. 263; por. też Parnowski, 2010; Leszek, Trypka, 2016].

6 Test ten nazywany jest również Testem płynności Chicago [Pąchalska, 2007, s. 59].

7 Anglojęzyczna nazwa FAS spopularyzowała się dzięki wersji COWAT (Controlled Oral Word Association) zawartej w Multilingual Aphasia Examination [Benton, Hamsher, 1976]. W teście tym wykorzystano trzy zestawy liter: 1) $f, a, s ; 2) c, f, l ; 3) p, r, w$. Ponieważ w badaniach najczęściej stosowano 
Test fluencji słownej stosowany jest jako samodzielne narzędzie diagnostyczne lub część większych badań, w tym znanych logopedom: Western Aphasia Battery [Kertesz, 1982], Bostońskiego testu diagnostycznego do badania afazji [Goodglass, Kaplan, 1972] czy Mattis Dementia Rating Scale. Supermarket [Mattis, 1988].

W praktyce logopedycznej wykorzystuje się kilka technik badania fluencji słownej: płynność semantyczną, formalną ${ }^{8}$, płynność w zakresie czasowników oraz nazw własnych [por. Rosińczuk-Tonderys, Murzyńska, Kazimierska-Zając, 2013; Żulewska, 2015; Gliwa, 2019a; 2019b; 2020]. W diagnozie neuropsychologicznej stosuje się także inne techniki pomiaru płynności, między innymi płynność syntaktyczną9, asocjacyjną ${ }^{10}$, afektywną ${ }^{11}$, kreatywną ${ }^{12}$, płynność rymów, płynność złożoną czy płynność rysowania [por. Pąchalska, 2007; Kircher i wsp., 2011; Szepietowska, Gawda, 2012; 2013; Piskunowicz i wsp., 2013].

\section{Fluencja słowna}

Fluencja to sprawność, $\mathrm{z}$ jaką tworzy się, planuje oraz wykonuje sekwencje niezautomatyzowanych czynności określonego rodzaju w ograniczonym czasie [Łojek, Stańczak, 2010, s. 91; por. też Szepietowska, Gawda, 2011]. Sprawność ta odnosi się do różnych procesów psychicznych, takich jak płynność słowna, niewerbalna, konstrukcyjna czy ruchowa [Szepietowska, Gawda, 2011, s. 9].

Terminem fluencja werbalna określa się proces doboru słów generowanych w określonym czasie, według ustalonego kryterium, spośród słów zakodowanych i skonsolidowanych w wyniku nabywania doświadczenia językowego w słowniku semantycznym [Łuczywek, Fersten, 1992, s. 90; por. też Jodzio, 2008; Szepietowska, Gawda, 2011; Szepietowska, Lipian, 2012; Whatmough, 2014].

f, a, s, tak zaczęto nazywać to narzędzie [Borkowski, Benton, Spree, 1967]. Do popularnych wersji testu należą: Test płynności złożonej [Butler, Rosman, Hill, 1993] i Test płynności Newcombe [Kolb, Whishaw, 2003].

$8 \mathrm{~W}$ niniejszych rozważaniach wielokrotnie odnoszę się do fluencji słownej formalnej w celu ukazania pewnej specyfiki wykonań zadań fluencji słownej semantycznej. Fluencja słowna formalna inaczej nazywana jest fluencją literową, ortograficzną i fonemiczną [Szepietowska, Gawda, 2011, s. 11]. Zadaniem badanego jest wymienić jak najwięcej słów rozpoczynających się od określonej głoski, na hasło: Proszę wymienić jak najwięcej słów rozpoczynających się od [np.] $k$.

9 Wymienianie słów określonego rodzaju gramatycznego [Szepietowska, Gawda, 2011, s. 11].

10 Tzw. płynność swobodna, skojarzeniowa, w której należy wymienić słowa „przychodzące do głowy" [por. Heim, Eickhoff, Amunts, 2008].

11 Podawanie egzemplarzy z kategorii afektywnych, na przykład przyjemne, nieprzyjemne [por. Rossell, 2006].

12 Wymaga wymienienia jak największej liczby sposobów użycia określonego przedmiotu [por. Moritz i wsp., 2002]. 
Wykonując zadania płynności semantycznej, korzystamy głównie z tak zwanej wiedzy kategorialnej, toteż niezbędne jest odniesienie się do terminu słownik semantyczny.

\section{Słownik semantyczny}

Słownik umysłowy (leksykon umysłowy, mentalny) to system słownictwa funkcjonujący w umyśle człowieka, na który składają się hasła odpowiadające poszczególnym jednostkom leksykalnym. Hasło leksykalne zawiera informację odnoszącą się do formy oraz informację wskazującą na znaczenie i sposób użycia określonej jednostki słownikowej [Berko Gleason, Bernstein Ratner, 2005, s. 28-29; por. też Nęcka, Orzechowski, Szymura, 2007]. Pamięć semantyczna to wiedza o faktach oraz znaczeniach słów i pojęć, zorganizowana w kategoriach [Pąchalska, 2007, s. 59, 94]. Kategoryzacja wiąże się z uruchamianiem semantycznych skojarzeń niezbędnych do wydobywania nazw z leksykonu umysłowego. Za „prawidłowy stan” kategorii semantycznych odpowiedzialna jest pamięć semantyczna. Kategoria semantyczna to minimum znaczeniowe tkwiące w świadomości ludzi, składające się na ich wiedzę referencjalną [Zawadzka, 2013, s. 35]. Płynne „przywoływanie” słów adekwatnych do wyznaczonego kryterium możliwe jest dzięki sieciom semantycznym łączącym pojęcia w określone zbiory, mechanizmowi aktywacji leksykalnej oraz sprawności podstawowej - możliwości rozumienia komunikatów werbalnych [por. Kielar-Turska, Byczewska-Konieczny, 2014].

W literaturze odnajdujemy różne hipotezy na temat organizacji słownika semantycznego i czynników regulujących dostęp leksykalny [Berko Gleason, Bernstein Ratner, 2005, s. 219-225; por. Field, 2004; Nęcka, Orzechowski, Szymura, 2007]. Jednym z najczęściej przywoływanych modeli organizacji słownika semantycznego jest model rozprzestrzeniającej się aktywacji, w którym pojęcia rozumie się jako rodzaje węzłów w łączącej je sieci. Ważnym elementem modelu jest twierdzenie o rozprzestrzenianiu się aktywacji: kiedy pobudzone zostaje jakieś pojęcie, pobudzone zostają także pojęcia $\mathrm{z}$ nim powiązane - jest to tzw. zjawisko torowania semantycznego. Dotarcie do pożądanego słowa powoduje uaktywnianie się kolejnych powiązanych z nim semantycznie [Berko Gleason, Bernstein Ratner, 2005, s. 182] ${ }^{13}$. Badania dowodzą, że związki natury semantycznej między słowami są silniejsze niż na przykład ich podobieństwo zewnętrzne - jeżeli umieścimy obok siebie dwa słowa o zbliżonym znaczeniu lub więcej, rozpoznanie jednego słowa uruchomi szybsze (niż w przypadku słów niepowiązanych semantycznie) rozpoznanie pozostałych, eksploracja jednego ułatwia zatem eksplorację kolejnych, pozostających z nim w relacji

13 Por. wyniki eksperymentów dotyczących decyzji leksykalnych Jean Berko Gleason i Nan Bernstein Ratner [2005, s. 182]. 
semantycznej. Dostęp do słownika semantycznego ma charakter elastyczny, aktywacja danego słowa może odbywać się na podstawie różnych kryteriów, najczęściej znaczenia, w dalszej kolejności częstotliwości użycia czy kategorii gramatycznej [Berko Gleason, Bernstein Ratner, 2005, s. 186].

Wspomina się o kilku modelach dostępu leksykalnego - najczęściej przytaczane to model przeszukiwania szeregowego i model dostępu równoległego, ku któremu skłania się większość badaczy [Berko Gleason, Bernstein Ratner, 2005, s. 185-200; por. też Nęcka, Orzechowski, Szymura, 2007]14.

\section{Badanie płynności słownej semantycznej}

W teście płynności słownej semantycznej - kategorialnej zadaniem badanego jest wymienić jak najwięcej słów należących do danej kategorii semantycznej ${ }^{15}$ - szerokiej lub wąskiej. Przyjmuje się, że kategoria szeroka to zbiór wyrazów powiązanych semantycznie, o licznej reprezentacji w słowniku mentalnym większości członków danej społeczności. Najczęściej w jej obrębie wyróżnia się podkategorie, na przykład w kategorii zwierzęta: ryby, ptaki, ssaki, zwierzęta domowe, hodowlane itd. [Łuczywek, Fersten, 1992, s. 93; Ponichtera-Kasprzykowska, Sobów, 2014, s. 180]. Kategorie wąskie tworzą zbiory wyrazów mających statystycznie małą frekwencję w słowniku mentalnym większości członków danej społeczności, można do nich zaliczyć na przykład nazwy ostrych przedmiotów, mebli, drzew itd. [Łuczywek, Fersten, 1992, s. 93; Ponichtera-Kasprzykowska, Sobów, 2014, s. 180].

\section{Przebieg badania}

Badanie za pomocą TFS nie wymaga użycia skomplikowanych narzędzi ani procedur, co jest jego niewątpliwą zaletą. W literaturze podkreśla się, że test postrzegany jest przez badanych jako narzędzie „mało zagrażające”"16. Można go wykonywać

14 Modele dostępu leksykalnego szczegółowo opisano w pracy J. Berko Gleason i N. Bernstein Ratner [2005, s. 185-200; por. też Nęcka, Orzechowski, Szymura, 2007].

15 Nie ma zgodności co do kryterium wyboru kategorii - aby móc dokonywać oceny porównawczej, warto wykonywać próby, które mają liczne opisy w literaturze.

16 Nie do końca można zgodzić się z tą opinią - w badaniach prowadzonych zarówno wśród osób zdrowych, jak i ze zdiagnozowanymi zaburzeniami poznawczymi bez cech otępienia i z otępieniem w stopniu lekkim obserwuje się objawy napięcia emocjonalnego podczas wykonywania testu. Badani odbierają zadanie jako banalne, toteż pojawiające się trudności z wygenerowaniem kolejnych egzemplarzy zbioru wprawiają ich w zakłopotanie. Taka reakcja bywa rzadsza u pacjentów z otępieniem w stopniu średnim i w zasadzie nie jest obserwowana u osób ze zdiagnozowanym otępieniem w stopniu głębokim. Należy to wiązać ze stopniową utratą krytycyzmu w stosunku do oceny własnych możliwości. 
w zasadzie w każdych warunkach, także w badaniu przyłóżkowym [Stolarska i wsp., 2008, s. 765]. Jego atutem jest wysoka odporność na efekt uczenia się, można go przeprowadzać w interwałach sześciomiesięcznych, odwołując się do tych samych kategorii. Warto pamiętać, aby podczas usprawniania fluencji słownej nie korzystać z kategorii, które były/będą podstawą oceny, chyba że celem jest ocena efektu uczenia się danego zadania.

Przed przystąpieniem do testu warto przygotować sobie nośnik rejestrujący dźwięk lub odpowiedni arkusz ułatwiający zapisywanie odpowiedzi, jeżeli badany nie wyrazi zgody na nagrywanie. Polecenie należy powtórzyć tyle razy, aż uzyska się pewność, że badany je zrozumiał, bądź że nie ma takiej możliwości. Powtarzamy je także w trakcie realizacji zadania, jeżeli badany o to poprosi, co należy odnotować, ponieważ wskazuje na obecność zaburzeń pamięci bądź zaburzeń koncentracji. Jeżeli w efekcie pojawienia się dystraktora badany zapomina, że był w trakcie wykonywania zadania, informację taką notujemy (należy zadbać o to, by dystraktory się nie pojawiały, chyba że celem badania jest ocena ich wpływu na wyniki TFS). Na wykonanie próby przeznacza się na ogół 60 sekund [por. Daniluk, 2000; Stolarska i wsp., 2008; Daniluk, Szepietowska, 2009a; 2009b] ${ }^{17}$. W przypadku oceny fluencji słownej u pacjentów ze zdiagnozowaną chorobą wpływającą na spowolnienie psychomotoryczne lub z podejrzeniem jej występowania czas wykonania testu przedłuża się do 120 sekund [Szepietowska, Gawda, 2011, s. 12].

Podczas jednego badania warto wykonać przynajmniej dwie różne próby (np. w zakresie kategorii wąskiej i szerokiej lub fluencji semantycznej i formalnej), by wykluczyć lub potwierdzić obecność perseweracji do poprzednio realizowanego zadania. Z tego też powodu w badaniach porównawczych zaleca się, aby wykonywać próby w określonej, stałej kolejności [por. Gliwa, 2018; 2019a].

\section{Ocena wyników badań}

Pomimo powszechnie przyjętej opinii o dużej wartości testu nadal nie ma jasności, które wskaźniki wykonania są najbardziej przydatne w procesie diagnostycznym. Ocena logopedyczna powinna obejmować przede wszystkim te aspekty, które wskazują na jakość procesów językowych i stan słownika semantycznego.

Analiza wyników testu wymaga uwzględnienia zmiennych społeczno-demograficznych, wśród nich wymienia się najczęściej wiek, wykształcenie i płeć ${ }^{18}$.

17 Nie jest to jednak reguła, w Teście diagnostycznym do badania afazji czas na wykonanie zadania to 90 sekund, ale ocenę formułuje się na podstawie 60 sekund najwyższej produktywności [por. Goodglass, Kaplan, 1972], w badaniach z użyciem technik neuroobrazowania to 15 sekund [por. Wood i wsp., 2001].

18 Aktualne stanowiska badaczy na ten temat szczegółowo zostały omówione między innymi w pracach Ewy Małgorzaty Szepietowskiej i Barbary Gawdy [2011, s. 26-33; 2013, s. 59-63]. 


\section{Ocena ilościowa}

Ocena ilościowa obejmuje tzw. wynik produkcji słownej (word production - WP) [Biechowska i wsp., 2012, s. 46; por. Pąchalska, 2007]. Ponieważ wciąż nie opracowano norm ilościowych dla języka polskiego ${ }^{19}$, przyjmujemy te przewidziane dla języka angielskiego: w kategorii szerokiej to 15 słów wymienionych w ciągu 60 sekund, spełniających kryterium [Szepietowska, Gawda, 2011, s. 12; Piskunowicz i wsp., 2013, s. 475], a w próbach obejmujących kategorie wąskie to 11 słów [Piskunowicz i wsp., 2013, s. 475; por. też Szepietowska, Gawda, 2011] ${ }^{20}$.

\section{Ocena jakościowa}

Ocena jakościowa ma na celu wskazanie sposobów wyszukiwania słów i pobudzania procesu wyszukiwania, analizę generowanych przez badanego słów i ich zbiorów, analizę najczęściej popełnianych błędów i zjawisk świadczących o zaburzonym dostępie do słownika mentalnego. Poniżej omówiono mechanizmy wydobywania słów oraz zjawiska najczęściej notowane podczas realizacji TFS.

Mechanizmy wydobywania słów, klucz wydobycia

Istnieją dwie strategie wykonywania zadań fluencji słownej, prowadzące do osiągnięcia wysokiego rezultatu: po pierwsze - badany może dysponować odpowiednio bogatym leksykonem, ma zatem łatwy dostęp do danego rodzaju informacji magazynowanych w pamięci; po drugie - może mieć zdolność szybkiej zmiany nastawienia umysłowego z wyrazu na wyraz, czyli łatwość przeszukiwania wielu różnych rodzajów danych [Biechowska i wsp., 2012, s. 49]. Większość wyników badań prowadzonych wśród „zdrowej” populacji potwierdza tendencję do semantycznego grupowania materiału niezależnie od zastosowanego kryterium zadania [Piskunowicz i wsp., 2013, s. 477]21.

Część badaczy wiąże niskie wyniki we wszystkich zadaniach fluencji słownej z dysfunkcją płatów czołowych [por. Szatkowska, Grabowska, Szymańska, 2000]. Istnieją jednak badania sugerujące, że płaty czołowe są związane $\mathrm{z}$ fluencją formalną, a skroniowe z semantyczną, zwłaszcza w podstawowych zadaniach fluencji słownej, które są przedmiotem niniejszego omówienia ${ }^{22}$ [Troyer, 2000; Henry, Crawford, Phillips, 2004; Birn i wsp., 2010].

19 Wyjątkiem są normy opracowane dla jednej grupy wiekowej i wybranych prób przez Adama Wysokińskiego i współautorów [2010, s. 438-446].

20 Urszula Stolarska i współautorzy [2008, s. 766] przyjmują, że dla kategorii szerokich norma to 20 słów, a dla wąskich 16 .

21 Interesujące wyniki badań uzyskali Jonathan L. Freedman i Elizabeth F. Loftus. Stwierdzili oni, że badani są w stanie nazwać więcej owoców zaczynających się na literę $p$ niż słów na literę $p$, które są owocami - i czynili to szybciej [Berko Gleason, Bernstein Ratner, 2005, s. 187].

$22 \mathrm{Na}$ ogół badacze przyjmują pogląd o współdziałaniu różnych obszarów mózgu podczas realizacji złożonych zadań fluencji słownej [por. Szepietowska, Gawda, 2011]. 
Najnowsze badania sugerują też zmienne zaangażowanie obu półkul w realizację zadań fluencji słownej. W tym miejscu w celu ukazania mechanizmów generowania słów należy odnieść się do procesu wydobywania słów w zadaniach fluencji formalnej, ponieważ strategia ta bywa stosowana przez pacjentów z AD do realizacji zadań fluencji słownej semantycznej. Lewa półkula aktywuje strategie oparte na podobieństwie/wskazówkach wewnętrznych (np. brzmieniowych), co kształtuje efektywność wykonania fluencji formalnej, natomiast prawa półkula wykorzystuje strategie holistyczne, heurystyczne, metaforyczne, wyobrażeniowe, stąd jej udział może zaznaczać się wyraźniej w zakresie fluencji semantycznej, ale także w zakresie wyboru strategii semantycznej w zadaniach fluencji formalnej [Goulet i wsp., 1997; Szepietowska, Lipian, 2012, s. 540-541; Piskunowicz i wsp., 2013, s. 481]23. Półkula lewa bierze udział we wczesnych etapach przypominania, w uruchamianiu silnych, prototypowych, zrutynizowanych relacji między pojęciami, co automatycznie aktywuje sieć semantyczną i ułatwia efektywne rozpoczęcie zadania [Elfgren, Reisberg, 1998]. Prawej półkuli przypisuje się udział w późniejszych etapach aktualizacji [Szepietowska, Gawda, 2011, s. 16].

\section{Klastry (clusters)}

Jednym z parametrów analizy jakościowej jest ocena możliwości generowania tzw. klastrów (clusters) - zbiorów, skupień słów powiązanych dodatkowo semantycznie lub formalnie w obrębie danego kryterium [Jodzio, 2006, s. 5-18; Biechowska i wsp., 2012, s. 46].

Słowa podawane przez badanego w próbie fluencji semantycznej uznajemy za klaster wówczas, gdy minimum dwa z nich należą do podkategorii semantycznej - na przykład nazwa podkategorii z jej choć jednym reprezentantem ${ }^{24}$ : gady, wą̇ [Biechowska i wsp., 2012, s. 46].

Tworzenie zbiorów może odbywać się także z wykorzystaniem klucza formalnego na bazie pierwszej litery, sylaby, pierwszych głosek bądź rymu, np. słoń, koń ${ }^{25}$ [por. Biechowska i wsp., 2012].

Mogą zdarzyć się także inne, specyficzne sposoby wydobywania - łączenia słów należących do danego zbioru, na przykład poprzez wykorzystywanie związków frazeologicznych, przysłów, powiedzeń (kot i pies, wilk i owca). Przywołując je, korzystamy ze strategii prawopółkulowych - tak jak w przypadku generowania ciągów zautomatyzowanych. Dostęp do nich w przebiegu otępienia w AD, zwłaszcza

23 Osoby z uszkodzeniem lewej półkuli uzyskują niższe wyniki we fluencji literowej niż semantycznej. Po uszkodzeniu prawej półkuli wzorzec jest odwrotny [Szepietowska, Lipian, 2012, s. 540].

$24 \mathrm{~W}$ otępieniu w przebiegu AD obserwuje się łatwiejszy dostęp do nazw kategorii semantycznych i ich podkategorii niż jej poszczególnych egzemplarzy.

25 Poprawność tak utworzonych skupisk podważają między innymi Philippe H. Robert i współautorzy [1998; za Biechowska i wsp., 2012]. 
we wczesnych etapach choroby, jest łatwiejszy niż przeszukiwanie zasobów pamięci semantycznej [Szepietowska, Lipian, 2012, s. 3].

Tworzenie klastrów na podstawie klucza formalnego - brzmieniowego ${ }^{26}$ przez osoby ze zdiagnozowaną AD jest dość charakterystyczne [por. Szepietowska, Gawda, 2016]. Wraz z narastaniem otępienia w kolejnych fazach AD obserwuje się stopniową przewagę klastrów opartych na strategii fonetycznej [por. Gliwa, 2019a, s. 66]. Można to wiązać $z$ lepszym funkcjonowaniem płatów czołowych niż skroniowych. Płaty czołowe, szczególnie okolica dolnego zakrętu czołowego (IFG), dokonują selekcji pojęć ze względu na aspekt fonologiczny [Szepietowska, Gawda, 2016, s. 172]. Płaty skroniowe w znacznej mierze odpowiadają za semantyczne grupowanie nazw. Upośledzenie ich funkcjonowania w wyniku procesu neurodegeneracji wiąże się ze słabnięciem sieci semantycznych w słowniku umysłowym [Szepietowska, Lipian, 2012, s. 541]. Nieliczne egzemplarze w klastrach dowodzą rozpadu pamięci semantycznej [por. Henry, Crawford, Phillips, 2004; Marczinski, Kertesz, 2006].

\section{Przełączanie (switching)}

Tworzenie klastrów związane jest $\mathrm{z}$ odmiennymi funkcjami poznawczymi i strukturami ośrodkowego układu nerwowego niż zdolność przełączania się (tzw. switching). Zdolność przełączania się na kolejny zbiór wyrazów wymaga od badanego tzw. elastyczności umysłowej i podzielności uwagi, toteż często zdolność wyszukiwania i rozpoczynania kolejnego zbioru łączona jest $\mathrm{z}$ funkcjami wykonawczymi i pamięcią operacyjną, a więc z aktywnością płatów czołowych [Mayr, 2002; Rende, Ramsberger, Miyake, 2002, s. 309-321; Biechowska i wsp., 2012, s. 46]. Parametry oceny możliwości przełączania się opracowane zostały przez Philippe H. Roberta i współautorów [1998], a dostosowane do języka polskiego przez Krzysztofa Jodzio [2006].

Można wyróżnić dwa typy przełączeń - w zależności od tego, czy wystąpi po nich nowy klaster, czy pojedyncze słowo, nierozpoczynające nowej wiązki. Przełączenia mogą mieć charakter bezpośredni, gdy po jednym skupisku pojawi się następne, gdy jednak kolejne słowa nie tworzą skupiska, mówimy o tzw. przejściu twardym [Piskunowicz i wsp., 2013, s. 477].

Rozmiar klastrów to suma liczby słów w każdym skupisku minus jeden, podzielona przez liczbę klastrów [por. Szepietowska, Gawda, 2011; Biechowska i wsp., 2012]27.

Analiza możliwości tworzenia skupień i sprawnego przełączania jest informacją na temat specyficznych zjawisk poznawczych, tzn. integralności magazynu leksykalno-semantycznego oraz sprawności przełączania z wyczerpanej kategorii na nową. Obniżenie liczby przełączeń wydaje się korelować z patologią czołową oraz

26 Na wyniki badań wpływa także specyfika danego języka, na przykład duża frekwencja danej głoski w nagłosach wyrazów należących do badanej kategorii.

27 Nie ma wskazań dotyczących pożądanej normatywnej objętości klastrów. 
podkorową, natomiast znaczne zmniejszenie pojemności zbiorów odzwierciedla upośledzenie funkcji płatów skroniowych [Biechowska i wsp., 2012, s. 46; por. De Gaspari, Siri, Di Gioia, 2006]. Większa liczba przełączeń i mniejszy rozmiar subkategorii mogą świadczyć o przewadze sprawności procesów wykonawczych nad pamięciowymi czy też o osłabieniu funkcji mnestycznych i kompensacji ze strony funkcji wykonawczych. Efekt taki powinien być szczególnie widoczny we fluencji semantycznej w stosunku rozmiaru subkategorii do liczby przełączeń, ponieważ zarówno zadanie (fluencja semantyczna), jak i typ strategii (przywołanie wielu powiązanych semantycznie elementów w jednym ciągu) angażować powinny procesy mnestyczne w większym stopniu niż wykonawcze, a więc bardziej okolice skroniowe niż czołowe [Stolarska i wsp., 2008, s. 766] ${ }^{28}$.

Liczba przytoczonych kategorii bywa uznawana za wynik świadczący o giętkości poznawczej, a ich rozmiar za miarę sprawności przeszukiwania słownika semantycznego [Troyer i wsp., 1998, s. 499-504; Biechowska i wsp., 2012, s. 46].

\section{Błędy}

Za odpowiedzi błędne uważa się przywołania słów innych niż pożądane, tj. niezgodnych $\mathrm{z}$ kryterium zadania. Mogą one być w jakimś zakresie styczne z poszukiwanymi bądź zupełnie przypadkowe. Ich generowanie można tłumaczyć, poza obecnością zaburzeń rozumienia i alogią, także hipotezą deficytu transmisji i deficytu hamowania [por. Kielar-Turska, Byczewska-Konieczny, 2014; Rutkiewicz-Hanczewska, 2016].

Hipoteza deficytu transmisji wiązana jest $\mathrm{z}$ tzw. siłą asocjacyjną słowa, tzn. jeżeli połączenie pomiędzy leksykalną a fonologiczną reprezentacją słowa jest na tyle słabe, że aktywacja pierwszego rodzaju reprezentacji nie wywołuje dostatecznie dużego pobudzenia drugiego rodzaju, obserwowana jest niemożność przypomnienia sobie pożądanego słowa [Kielar-Turska, Byczewska-Konieczny, 2014, s. 439-440].

Pojawiające się błędy można tłumaczyć hipotezą deficytu hamowania słów powiązanych semantycznie, morfologicznie lub dźwiękowo. W chwili poszukiwania adekwatnego słowa aktywowane są także te $\mathrm{z}$ nim powiązane i są one bardziej dostępne niż poszukiwane. Pojawienie się „blokerów”, „intruzów” powoduje zaburzenia procesu interferencji, czyli możliwości przetwarzania istotnego bodźca, w efekcie czego proces przeszukiwania zostaje odsunięty od pożądanego słowa [Kielar-Turska, Byczewska-Konieczny, 2014, s. 439]. Spadek zdolności hamowania wiąże się między innymi z nasileniem efektu zaniedbywania celu, który ma miejsce, kiedy cele ulegają dysocjacji od aktualnego działania jednostki [Kielar-Turska, Byczewska-Konieczny, 2014, s. 439].

- Błędy semantyczne

Błędy semantyczne (parafazje semantyczne) to przywołania wyrazów innych niż docelowe, ale pozostających z nimi w określonej relacji semantycznej (wyraz

28 Nie wszystkie wyniki badań potwierdzają te zależności [Stolarska i wsp., 2008, s. 767]. 
docelowy i zaktualizowany mają element wspólnego znaczenia). Najczęściej pojawiają się hiperonimy (znaczenie jednej jednostki leksykalnej o bardziej ogólnej treści i szerszym zakresie zawiera w sobie znaczenie drugiej jednostki - np. przywołania nazw podkategorii danej kategorii semantycznej: ptak zamiast wróbel), meronimy (słowa oznaczające część pewnej całości, np. składnik zamiast obiektu: ogony zamiast nazwy zwierzęcia), synonimy (np. obcojęzyczne odpowiedniki słowa docelowego: horse zamiast koń) ${ }^{29}$. Możliwe jest także wykorzystanie określonej, często zaskakującej styczności, na przykład w kategorii ostre przedmioty: papryka, ostra zima, ostry zakręt. Dziwaczne, metaforyczne nazwy, niestandardowe skojarzenia mogą świadczyć o lepszym funkcjonowaniu prawej półkuli, której przypisuje się udział w uruchamianiu skojarzeń odległych [Szepietowska, Gawda, 2011, s. 16; por. Pąchalska, MacQueen, 1998; Rutkiewicz-Hanczewska, 2016].

Błędy semantyczne mogą być efektem zaburzeń mechanizmów kontrolujących przebieg zadania, gdy badani nieświadomie „przełączają się” na inne kryterium wyszukiwania, inną kategorię semantyczną - łatwiejszą do zrealizowania, na przykład w kategorii nazw ostrych przedmiotów: nóż, łyżka, nóż, łyżka, miska [Gliwa, 2019a, s. 62].

Specyficzną (bo uświadomioną) formą błędu semantycznego jest tzw. negacja semantyczna, na przykład nie łyżka, tylko... (widelec).

Liczba błędów semantycznych w otępieniu w przebiegu AD zazwyczaj rośnie adekwatnie do stopnia otępienia, osiągając apogeum w otępieniu w stopniu średnim, zmniejszając się już we wczesnych fazach otępienia głębokiego, stosownie do zmniejszającej się ogólnej produkcji słownej [por. Gliwa, 2019a].

- Błędy formalne

Notowane w odpowiedziach badanych błędy formalne, świadczące często o szczątkowej wiedzy na temat struktury poszukiwanego wyrazu, przybierają najróżniejszą postać, nawiązując do struktury poszukiwanego słowa.

Można tu wymienić parafazje fonologiczne, kombinacje fragmentów struktur synonimicznych (kontaminacje), parafazje neologistyczne oraz parafazje leksykalne [Rutkiewicz-Hanczewska, 2016, s. 106-107].

Parafazje fonologiczne to struktury, które w jakimś zakresie fonologicznie przypominają wyraz docelowy, ale nie należą do słownika danego języka. U ich podłoża leży wadliwa reprezentacja fonologiczna dźwięków, stąd możliwe substytucje, metatezy, elizje, epentezy. Parafazje neologistyczne przypominają błędy fonemiczne, w żaden sposób nie można powiązać ich z zasobami słownikowymi danego języka, zalicza się do nich także palilalie [Rutkiewicz-Hanczewska, 2016, s. 107-108]. Specyficznym błędem formalnym będą parafazje

29 Mogą to być także wyrazy należące do różnych odmian stylistycznych, na przykład burek zamiast pies, wówczas nie kwalifikujemy ich jako błędy semantyczne. 
leksykalne, gdy zamiast pożądanego słowa przytoczone zostanie słowo bliskobrzmiące.

Narastające wraz z rozwojem otępienia niepłynności i błędy w strukturze słowa świadczą o rozpadzie zautomatyzowanych procesów formułowania języka. Nasilają się one w otępieniu w stopniu głębokim [por. Gliwa, 2019a].

- Wyrazy przypadkowe

Wyrazy przypadkowe to wyrazy, które ze słowem docelowym nie mają żadnego związku - ani na poziomie fonologicznym, ani znaczeniowym [por. Rutkiewicz-Hanczewska, 2016]. Mogą wynikać z alogii, co wskazuje na dysfunkcje procesów semantycznych [Szepietowska, Gawda, 2011, s. 33]. Osoby z otępieniem w stopniu głębokim mają tendencję do wymieniania tego, co mają przed oczyma, co może świadczyć o inercyjności myślenia [por. Gliwa, 2019a].

\section{"Mam to na końcu języka" - TOT}

Syndrom TOT to rodzaj anomii produkcji słów - charakterystyczny stan metakognitywny, wynikający z częściowej aktywacji poziomu fonologicznego ${ }^{30}$ wyszukiwania wyrazów za pośrednictwem systemu semantycznego. Zjawisko TOT obserwuje się w sytuacji, gdy badany jest w stanie wskazać cechy semantyczne lub gramatyczne poszukiwanego słowa, jednak od strony fonologicznej ma dostęp do ograniczonej informacji na jego temat, takiej jak na przykład liczba sylab, pierwsza ${ }^{31}$, ostatnia głoska, miejsce padania akcentu [Rutkiewicz-Hanczewska, 2016, s. 90-98; por. też Kielar-Turska, Byczewska-Konieczny, 2014]. Zjawisko to zazwyczaj wiązane jest z omówionymi wyżej deficytem transmisji i hipotezą blokowania. Efektem obecności syndromu TOT mogą być zjawiska o charakterze kompensacji, jak na przykład peryfrazy czy stosowanie komunikacji niewerbalnej.

\section{Peryfrazy}

Peryfrazy to zastępcze omówienia w chwili braku dostępu do poszukiwanego słowa. Mogą być tworzone w różny sposób i zawierać cechy definicyjne lub nie (w miarę narastania otępienia przybierając formę tzw. mowy zaimkowej, np. w kategorii nazw zwierząt: no ten, wiesz kochana, takiego miałam...). Mogą być wyrażone wprost lub $\mathrm{w}$ postaci semantycznej negacji, na przykład: to nie jest siekiera (poszukiwany wyraz tasak w kategorii ostre przedmioty), mogą zawierać nazwę kategorii podstawowej, na przykład: wszystkie stolarskie ostre przedmioty... [Gliwa, 2019a, s. 52]. Interesujące wyniki badań przedstawiłam w pracy z 2020 roku - wskazują one, że osoby $\mathrm{z}$ otępieniem w przebiegu AD mają tendencję do tworzenia deskrypcji, zwłaszcza

30 Dodatkowo w wieku starczym aktywacja poszczególnych poziomów dostępu ulega osłabieniu [Rutkiewicz-Hanczewska, 2016, s. 94].

31 Przy zachowanej pamięci pierwszej litery badani często piszą palcem na blacie stołu/w powietrzu, najczęściej jednak nie są w stanie zrealizować docelowego słowa. 
te $\mathrm{z}$ otępieniem w stopniu lekkim i średnim. Tendencja ta zmniejsza się w otępieniu w stopniu głębokim, gdy ogólna produkcja słowna jest znikoma [por. Gliwa, 2020].

\section{Peryfrazy niezwiązane}

Peryfrazy niezwiązane to przypadkowe omówienia generowane przez badanego [Rutkiewicz-Hanczewska, 2016, s. 113-114]. Są dość powszechne u pacjentów z otępieniem w stopniu głębokim [por. Gliwa, 2019a]. Zaliczamy do nich także niekompletne omówienia (np. zwierzę, które jest...) i niedokończone frazy (np. taki, co...).

\section{Gest, konstrukcje werbalno-gestowe}

Brak dostępu do poszukiwanego słowa bywa kompensowany przez osoby z otępieniem w przebiegu AD komunikacją niewerbalną - gestem lub konstrukcjami werbalno-gestowymi ${ }^{32}$. Zwłaszcza w otępieniu w stopniu lekkim i średnim gest odgrywa rolę uzupełniającą [por. Domagała, 2007; 2019, s. 15; Gliwa, 2019a, s. 55]. Wykorzystywane są zarówno gesty referencyjne, jak i niereferencyjne.

Gesty referencyjne są generowane zamiast niedostępnego słowa, najczęściej są to gesty ikoniczne, czasem w konstrukcjach werbalno-gestowych mogą pojawić się ikinetografy (np. obrazujące różne czynności - naśladowanie czynności cięcia nożyczkami w kategorii nazw ostrych przedmiotów [Gliwa, 2019a, s. 55; por. Rutkiewicz-Hanczewska, 2016]). Z gestami ikonicznymi łączy się drugi typ kompensacji: pisanie/rysowanie w powietrzu/na blacie ${ }^{33}$. Mogą pojawić się także gesty deiktyczne, wskazujące rzecz, o której mowa, jeżeli pozwala na to badana kategoria semantyczna.

Gesty niereferencyjne (pozbawione znaczenia) odzwierciedlają referenta, obiekt, do którego się odnoszą, w sposób abstrakcyjny, całkowicie niebezpośrednio. Są wykorzystywane w sytuacji, gdy u mówiącego widać problem ze znalezieniem odpowiedniego wyrazu lub gdy ma on go „na końcu języka”. Najczęściej są to ideografy, które szkicują kierunek wypowiadanych myśli, na przykład ruchy ręki, będące komunikatem w znaczeniu „przecież wiesz, o co mi chodzi” [por. Rutkiewicz-Hanczewska, 2016].

\section{Onomatopeje}

Brak gotowości słowa może być kompensowany wyrażeniem dźwiękonaśladowczym, zwłaszcza w takich kategoriach jak nazwy zwierząt czy nazwy ostrych przedmiotów. Możliwe są także peryfrazy zawierające konstrukcje werbalno-gestowo-parajęzykowe

32 Badania wskazują, że możliwość kompensowania deficytów językowych gestem uzależniona jest od miejsca patologii mózgowia - osoby z patologią półkuli lewej wykonują znacznie więcej gestów przestrzennych niż osoby, u których diagnozuje się ją w obrębie półkuli prawej [por. Rutkiewicz-Hanczewska, 2016].

33 Umiejętność rysowania ma charakter nielingwistyczny [Rutkiewicz-Hanczewska, 2016, s. 136]. 
(np. No te! Ciach, ciach - badana osoba wykonuje jednocześnie ruch naśladujący cięcie papieru nożycami [por. Gliwa, 2019a, s. 55]).

\section{Ominięcia}

Ominięcia świadczą o degradacji słownika semantycznego, stanowią charakterystyczną formę anomii [por. Rutkiewicz-Hanczewska, 2016]. Możemy o nich mówić, gdy badany nie generuje żadnych pożądanych słów, ma jednak zachowaną możliwość rozumienia polecenia. Rozpad słownika semantycznego może przejawiać się milczeniem - ciszą w odpowiedzi na polecenie, werbalizacją braku dostępu do nazwy: nie wiem, nie umiem powiedzieć, nic mi nie przychodzi do głowy lub inicjacją wypowiedzi: na ka, na ka to by było, zwierzęta to sa... [Gliwa, 2019a, s. 57; por. Rutkiewicz-Hanczewska, 2016].

\section{Redundantne gadulstwo - OTV (off-target verbosity)}

U pacjentów $\mathrm{z}$ otępieniem w przebiegu AD, szczególnie w stopniu średnim, obserwuje się zaburzenia o charakterze pragmatycznym, przejawiające się tzw. redundantnym gadulstwem. Syndrom OTV 34 świadczy o spadku spójności wypowiedzi w efekcie deficytu możliwości hamowania informacji nieistotnych z punktu widzenia aktualnego celu komunikacyjnego, a w przypadku realizacji TFS - celu zadania. Przejawia się to przeładowaniem wypowiedzi dygresjami [Kielar-Turska, Byczewska-Konieczny, 2014, s. 440]. W przebiegu AD zjawisko to nasila się i łączy z patologicznym rozpraszaniem uwagi, zaburzeniami koncentracji i prowadzi do gubienia celu zadania. W ostatnich fazach otępienia zastępuje je zjawisko zgoła odmienne - mutyzm.

\section{Perseweracje, powtórzenia (wypełniacze)}

Perseweracje to dość częste zjawisko pojawiające się podczas realizacji TFS. Najczęściej notuje się:

1) powtórzenia słowa już wcześniej wypowiedzianego, bez świadomości, że zostało już wcześniej wypowiedziane;

2) powtórzenia ze świadomością, że dana nazwa już się pojawiła, co sugeruje, że mechanizm kontroli realizacji zadania działa $\mathrm{z}$ opóźnieniem ${ }^{35}$, na przykład: to już mówiłam, to już chyba było [Gliwa, 2019a, s. 51];

3) perseweracje werbalne - mimowolne, nieadekwatne powtórzenia poprzednich słów; mogą one mieć charakter ciągły lub nieciągły; są efektem wadliwie działającego mechanizmu blokowania w tzw. pętli sensoryczno-motorycznej mowy

34 Syndrom skorelowany jest z wiekiem [Kielar-Turska, Byczewska-Konieczny, 2014, s. 440].

35 Jest to zjawisko charakterystyczne dla grupy wiekowej poniżej 65. roku życia. Jego nasilenie wiąże się z uszkodzeniami kory przedczołowej [Kielar-Turska, Byczewska-Konieczny, 2014, s. 437]. 
[Szczepańska-Gieracha, Greń, Morga, 2014, s. 74]; są charakterystyczne w otępieniu głębokim;

4) perseweracje kategorii - gdy badany powraca do wcześniej realizowanej kategorii lub w jakiś sposób kontaminuje dwa zadania (zjawiska obserwowane głównie u pacjentów z otępieniem w stopniu średnim [por. Gliwa, 2019a]).

Te cztery typy perseweracji powodowane są zaburzeniami pamięci i zaburzeniami funkcji wykonawczych, których zadaniem jest między innymi monitorowanie poprawności przebiegu zadania.

Kolejne formy powtórzeń to specyficzne sposoby pobudzania - uaktywniania słownika semantycznego. Są to wypełniacze - świadome jedno- lub wielokrotne powtórzenia wcześniej wypowiedzianego wyrazu, na przykład [...] baran... baran... baran..., co tam jeszcze... lub powtarzanie polecenia [Gliwa, 2019a, s. 51]. Te typy powtórzeń, choć świadczą o obniżonej efektywności przeszukiwania słownika mentalnego i typowych dla osób $\mathrm{z}$ otępieniem w przebiegu AD trudnościach w zakresie inicjowania czynności [Sellal, Wolff, Marescaux, 2004], pomagają pobudzić proces wyszukiwania kolejnych słów (por. mechanizm aktywacji leksykalnej) [Kielar-Turska, Byczewska-Konieczny, 2014, s. 437-439].

\section{Fluencja semantyczna u osób ze zdiagnozowaną chorobą Alzheimera}

Jednym z objawów otępienia alzheimerowskiego jest ubożenie zasobów leksykonu umysłowego w miarę narastania demencji [por. Szepietowska, Daniluk, 2000; Szepietowska, Gawda, 2012; Domagała, 2015]. Najistotniejszym objawem zaburzeń fluencji słownej semantycznej są trudności z aktualizacją pojęć ${ }^{36}$, wynikające z rozległej patologii korowej [Szepietowska, Gawda, 2011, s. 20] ${ }^{37}$. Atrofia korowa (szczególnie tylnego obszaru), taka jak w przebiegu $\mathrm{AD}$, wiąże się z niemożnością aktualizacji pojęći rozpadem zasobów pamięci semantycznej [Szepietowska, Gawda, 2011, s. 16-17; por. też Apostolova i wsp., 2008] ${ }^{38}$. Deficyty semantyczne są bardziej typowe dla AD niż deficyty wykonawcze [Henry, Crawford, Phillips, 2004; Szepietowska, Gawda,

36 John R. Hodges i współautorzy [1992], na podstawie wyników testów językowych przeprowadzonych wśród pacjentów ze zdiagnozowaną $\mathrm{AD}$, stwierdzili głębokie deficyty fluencji kategorialnej z pełnym brakiem przykładów z mniej typowych kategorii, jak na przykład rasy psów, obok deficytów w zakresie nazywania i definiowania [por. też Szepietowska, Daniluk, 2000, s. 117-135].

$37 \mathrm{Na}$ temat specyfikacji obszarów korowych i podkorowych w procesach fluencji słownej nadal prowadzone są dyskusje, podkreśla się jednak rolę obszarów korowych, podkorowych (wzgórze, ciało migdałowate, hipokamp), połączeń korowo-podkorowych, a także móżdżku [Szepietowska, Gawda, 2011, s. 20].

38 Patologia struktur podkorowych wpływa na zmniejszenie liczby przełączeń oraz ograniczenie liczebności klastrów. Należy to łączyć z deficytami strategii aktualizacji i - szerzej - z deficytami wykonawczymi, a nie rozpadem zasobów wiedzy [Szepietowska, Gawda, 2011, s. 19]. 
2012], dlatego wyniki badań wskazują, że chorzy ze zdiagnozowanym otępieniem w przebiegu AD lepiej realizują zadania z zakresu fluencji formalnej niż semantycznej [Whatmough, 2014, s. 12-13; por. Carew i wsp., 1997; Szepietowska, Daniluk, 2000; Ross, 2003; Szepietowska, Gawda, 2016].

Istotą deficytów pamięci semantycznej w AD jest trudność w identyfikacji specyficznych, niezbędnych dla pojęcia cech, ignorowanie cech mniej istotnych i utrzymanie wyników tych decyzji poznawczych w pamięci. Mniejsze trudności chorzy ujawniają w określeniu prototypowości egzemplarzy danej kategorii, co powoduje, że mogą generować słowa typowe dla danej kategorii, choć bardzo często wychodzą poza kryterium lub podają nazwy subkategorii [Grossman i wsp., 2001, s. 265-267]. Pacjentom nie pomaga udzielanie wskazówek semantycznych (np. to dzikie zwie$r z e)$ ani też formalnych, wręcz przeciwnie - podpowiadanie powoduje dezorientację [Whatmough, 2014, s. 12-13].

Rezultaty badań Emilii J. Sitek, Anny Barczak i Magdaleny Sendereckiej na podstawie analizy wyników skali ACE-III, w skład której wchodzi ocena fluencji słownej, wskazują, że u osób z $\mathrm{MCI}^{39}$, u których następuje później konwersja do otępienia w przebiegu $\mathrm{AD}$, obserwuje się obniżenie wyników w zakresie pamięci semantycznej (nazywania i fluencji semantycznej), obok dominujących zaburzeń pamięci epizodycznej [Sitek, Barczak, Senderecka, 2017, s. 36-37]. Z początkową fazą AD wiąże się obniżenie wyników w zakresie fluencji słownej, a w mniejszym nasileniu pozostałych funkcji językowych i wzrokowo-przestrzennych [Sitek, Barczak, Senderecka, 2017, s. 36-37]. U osób z czołowym wariantem AD (fvAD) w profilu zaburzeń na plan pierwszy wysuwa się znaczące obniżenie fluencji słownej, któremu towarzyszy obniżenie wyników podskali pamięci. W porównaniu z chorymi z klasyczną AD pacjenci z fvAD osiągają też znacząco gorszy wynik ogólny [por. Gleichgerrcht i wsp., 2011], prawdopodobnie uwarunkowany nasilonymi zaburzeniami funkcji wykonawczych [Sitek, Barczak, Senderecka, 2017, s. 37].

Choroba Alzheimera o wczesnym początku charakteryzuje się znacznie większą różnorodnością kliniczną niż postać późna AD (częstsze są tu warianty atypowe, takie jak zanik korowy tylny czy wariant logopeniczny pierwotnej afazji postępującej), mimo to większość pacjentów prezentuje profil kliniczny podobny do postaci późnej, czyli z dominującymi zaburzeniami uwagi, pamięci oraz funkcji wzrokowo-przestrzennych, głównie konstrukcyjnych. Ponadto obserwuje się znacznie bardziej nasilone deficyty funkcji wykonawczych, przekładające się na obniżenie wyniku fluencji słownej [Sitek, Barczak, Senderecka, 2017, s. 37; por. też Elamin i wsp., 2016].

39 MCI (mild cognitive impairment) - łagodne zaburzenia poznawcze bez cech otępienia. 


\section{Podsumowanie}

Realizacja zadań z zakresu płynności słownej wymaga umiejętności rozumienia komunikatów językowych, możliwości planowania czynności poprzez elastyczne stosowanie wybranej strategii działania (klucza wyszukiwania słów), w celu osiągnięcia jak największej liczby poprawnych realizacji, aktualizacji słów zgodnych z wyznaczonym kryterium, aż do zakończenia zadania, z uwzględnieniem czynności wykrywania i korekty błędów [Łojek, Stańczak, 2010].

Sposób realizacji zadań dotyczących fluencji słownej - tj. liczba generowanych pojęć zgodnych z kryterium, liczba klastrów i ich zasób, charakter błędów (powtórzeń, neologizmów) - świadczy o jakości procesów językowych, o stanie pamięci semantycznej i może być wykorzystany w diagnozie różnicowej otępienia [por. Szepietowska, Gawda, 2011, s. 11-14; 2012, s. 38-39; Gliwa, 2018, s. 83-102].

Trudności z aktualizacją pojęć mogą być istotnym objawem rozwijających się procesów otępiennych - zwłaszcza we wczesnym stadium AD, gdy zwraca się uwagę głównie na deficyty pamięci (dopiero w miarę postępowania choroby dostrzega się zakłócenia sfery językowej) [por. Parnowski, 1998; Podemski, Słotwiński, 2003; Gomez, White, 2006; Domagała, 2007; 2015].

Wykonanie fluencji semantycznej z typowym ograniczeniem podawanych pojęć różnicuje wczesną postać $\mathrm{AD}$ od naturalnego procesu starzenia się [Groves-Wright i wsp., 2004; Szepietowska, Gawda, 2012, s. 39].

Ponadto wyniki testów fluencji słownej są zazwyczaj gorsze niż rezultaty nazywania, co wskazuje na większą czułość testów fluencji słownej w wykrywaniu wczesnych objawów demencji [por. Szepietowska, Daniluk, 2000, s. 117-135; Szczepańska-Gieracha, Greń, Morga, 2014, s. 74].

\section{Literatura}

Apostolova L., Lu P., Rogers S., Dutton R., Hayashi K., Toga A., Cummings J., Thompson P., 2008, $3 D$ mapping of language networks in clinical and pre-clinical Alzheimer's disease, „Brain and Language", no. 104, s. 33-41.

Armstrong C.L., Morrow L., 2014, Otępienie, [w:] C.L. Armstrong, L. Morrow (red. wyd. pol. M. Harciarek), Neuropsychologia medyczna, Warszawa: Wydawnictwo Lekarskie PZWL, s. 3-33.

Barczak A., Gorzkowska A., Klimowicz-Morawiec A., 2012, Ocena zaburzeń funkcjonowania poznawczego, [w:] M. Zabawa (red.), Diagnostyka i leczenie otępień. Rekomendacje zespołu ekspertów Polskiego Towarzystwa Alzheimerowskiego, Otwock: Medisfera, s. 11-16.

Benton A.L., Hamsher K., 1976, Multilingual Aphasia Examination manual, Iowa City: AJA Associates.

Berko Gleason J., Bernstein Ratner N., 2005, Psycholingwistyka, Gdańsk: Gdańskie Wydawnictwo Psychologiczne. 
Biechowska D., Kaczmarek I., Witkowska M., Steinborn B., 2012, Przydatność prób fluencji słownej $w$ diagnozie różnicowej zaburzeń neurologicznych u dzieci i młodzieży, „Neurologia Dziecięca”, t. $21, \mathrm{nr} 42$, s. $45-51$.

Birn R.M., Kenworthy L., Case L., Caravella R., Jones T.B., Bandettini P.A., Martin A., 2010, Neural systems supporting lexical search guided by letter and semantic category cues: A self-paced overt response fMRI study of verbal fluency, „Neuroimage”, vol. 49, issue 1, s. 1099-1107.

Borkowski J.G., Benton A.L., Spree O., 1967, Word fluency and brain damage, „Neuropsychologia”, no. 5, s. 135-140.

Butler R.W., Rosman I., Hill J.M., 1993, The effects of frontal brain impairment on fluency. Simple and complex paradigms, „Neuropsychology”, vol. 7(4), s. 519-529.

Carew T.C., Lamar M., Cloud B., Grossman M., Lizbon D., 1997, Impairment in category fluency in ischemic vascular dementia, „Neuropsychology”, vol. 11(3), s. 400-412.

Daniluk B., 2000, Deficyty poznawcze u osoby z postępującym schorzeniem mózgu o etiologii naczyniowej. Neuropsychologiczne studium przypadku, [w:] A. Borkowska, E. Szepietowska (red.), Diagnoza neuropsychologiczna. Metodologia i metodyka, Lublin: Wydawnictwo Uniwersytetu Marii Curie-Skłodowskiej, s. 383-405.

Daniluk B., Szepietowska E.M., 2009a, Płynność semantyczna i literowa osób w różnych fazach dorosłości - część I, „Annales Universitatis Mariae Curie-Skłodowska. Sectio J. PaedagogiaPsychologia", nr 22, s. 97-110.

Daniluk B., Szepietowska E.M., 2009b, Płynność semantyczna i literowa osób w różnych fazach dorosłości - czynniki modyfikujące wykonanie zadań fluencji słownej - część II, „Annales Universitatis Mariae Curie-Skłodowska. Sectio J. Paedagogia-Psychologia”, nr 22, s. 111-128.

De Gaspari D., Siri C., Di Gioia M., 2006, Clinical correlates and cognitive underpinnings of verbal fluency impairment after chronic subthalamic stimulation in Parkinson's disease, „Parkinsonism and Related Disorders", no. 12, s. 289-295.

Domagała A., 2007, Zachowania językowe $w$ demencji - struktura wypowiedzi w chorobie Alzheimera, Lublin: Wydawnictwo Uniwersytetu Marii Curie-Skłodowskiej.

Domagała A., 2015, Narracja i jej zaburzenia w otępieniu alzheimerowskim, Lublin: Wydawnictwo Uniwersytetu Marii Curie-Skłodowskiej.

Domagała A., 2019, Rozpad sprawności leksykalnych u pacjenta z otępieniem umiarkowanym w chorobie Alzheimera, „Logopaedica Lodziensia”, nr 3, s. 45-61.

Domagała A., Sitek E., 2018, Choroba Alzheimera. Zaburzenia komunikacji językowej, Gdańsk: Wydawnictwo Harmonia.

Elamin M., Holloway G., Bak T.H., Pal S., 2016, The utility of the Addenbrooke's Cognitive Examination version three in early-onset dementia, „Dementia and Geriatric Cognitive Disorders", no. 41, s. 9-15.

Elfgren Ch., Reisberg J., 1998, Lateralised frontal blood flow increases during fluency task: influence of cognitive strategy, „Neuropsychology”, vol. 36(6), s. 505-512.

Field J., 2004, Psycholinguistics. The Key Concepts, Oxon: Blackwell.

Gleichgerrcht E., Chade A., Torralva T., Roca M., Manes F., 2011, Comparing the neuropsychiatric profile of patients with Alzheimer disease who present spared versus impaired executive functioning, „Current Gerontology and Geriatrics Research”, http://www.ncbi.nlm.nih.gov /pmc/articles/PMC3205715/ (dostęp: 11.01.2021).

Gliwa R., 2018, Fluencja słowna w otępieniu naczyniopochodnym - ujęcie kliniczne, [w:] E. Gacka, M. Kaźmierczak (red.), Teoria i praktyka logopedyczna. Wybrane zagadnienia, Łódź: Wydawnictwo Uniwersytetu Łódzkiego, s. 85-104.

Gliwa R., 2019a, Fluencja słowna w zakresie wybranych kategorii nazw własnych i pospolitych w przebiegu otępienia w chorobie Alzheimera, „Polonica”, nr 39, s. 45-70. 
Gliwa R., 2019b, Verbal fluency in categories of common and proper names in the phase of mild cognitive impairment in the course of Parkinson's disease, „Interdisciplinary Contexts of Special Pedagogy", no. 27, s. 249-272.

Gliwa R., 2020, Fluencja słowna czasownikowa w fazie otępienia w stopniu lekkim w przebiegu choroby Alzheimera, [w:] K. Bednarska, D. Kruk, B. Popov, O. Saprikina, T. Speed, K. Szafraniec, S. Terekhova, R. Tsonev, A. Wysocka (red.), Contributions to the $23^{\text {rd }}$ Annual Scientific Conference of the Association of Slavists (Polyslav), Wiesbaden: Die Welt der Slaven, s. $109-118$.

Gomez R., White D., 2006, Using verbal fluency to detect very mild dementia of the Alzheimer type, „Archives of Clinical Neuropsychology”, vol. 21, issue 8, s. 771-775.

Goodglass H., Kaplan E., 1972, Boston Diagnostic Aphasia Examination, Philadelphia: Lea \& Febiger.

Goulet P., Joanette Y., Sabourin L., Giroux F., 1997, Word fluency after a right-hemisphere lesion, „Neuropsychologia”, no. 35(12), s. 1565-1570.

Grossberg G.T., Kamat S.M., (red. wyd. pol. T. Sobów), 2011, Choroba Alzheimera. Najnowsze strategie diagnostyczne i terapeutyczne, Warszawa: Medisfera.

Grossman M., Robinson K., Bernhardt N., Koenig Ph., 2001, A rule-based categorization deficit in Alzheimer's Disease?, „Brain and Cognition”, no. 45, s. 265-276.

Groves-Wright K., Neils-Strunjas J., Burnett R., O’Neill M.J., 2004, A comparison of verbal and written language in Alzheimer's disease, „Journal of Communication Disorders”, no. 37, s. $109-130$.

Heim S., Eickhoff S.B., Amunts K., 2008, Specialization in Broca's region for semantic, phonological, and syntactic fluency?, „Neuroimage”, vol. 40, issue 3, s. 1362-1368.

Henry J., Crawford J., Phillips L., 2004, Verbal fluency performance in dementia of Alzheimer's type: a meta-analysis, „Neuropsychologia”, no. 42, s. 1212-1227.

Hodges J.R., Patterson K., Oxbury S., Funnell E., 1992, Semantic dementia. Progressive Fluent Aphasia with Temporal Lobe Atrophy, „Brain”, no. 115, s. 1781-1806.

Jodzio K., 2006, Neuropoznawcze korelaty spadku fluencji słownej po udarze prawej półkuli mózgu, „Studia Psychologiczne”, t. 44, nr 2, s. 5-18.

Jodzio K., 2008, Neuropsychologia intencjonalnego działania. Koncepcje funkcji wykonawczych, Warszawa: Wydawnictwo Naukowe Scholar.

Kertesz A., 1982, The Western Aphasia Battery: Test Manual, Stimulus Cards, Test Booklets (Test Kit), New York: Grune and Stratton.

Kielar-Turska M., Byczewska-Konieczny K., 2014, Specyficzne właściwości posługiwania się językiem przez osoby w wieku senioralnym, [w:] S. Milewski, J. Kuczkowski, K. Kaczorowska-Bray (red.), Biomedyczne podstawy logopedii, Gdańsk: Wydawnictwo Harmonia Universalis, s. 429-441.

Kircher T., Nagels A., Kirner-Veselinovic A., Krach S., 2011, Neural correlates of rhyming vs lexical and semantic fluency, „Brain Research”, vol. 1391, s. 71-80.

Kolb B., Whishaw I.Q., 2003, Fundamentals of Human Neuropsychology, New York: Worth Publishers.

Kozubski W., Liberski P.P., 2014, Neurologia, Warszawa: Wydawnictwo Lekarskie PZWL.

Leszek J., Trypka E., 2016, Choroba Alzheimera: problematyka neurozwyrodnienia. Wybrane zagadnienia, [w:] J. Leszek (red.), Choroba Alzheimera - wybrane zagadnienia biologiczne i kliniczne, Wrocław: Wydawnictwo Continuo, s. 11-27.

Łojek E., Stańczak J., 2010, Podręcznik do Kalifornijskiego Testu Uczenia się Językowego CVLT D.C. Delisa, J.H. Kramera, E. Kaplan i B. Ober. Polska normalizacja, Warszawa: Pracownia Testów Psychologicznych.

Łuczywek E., Fersten E., 1992, Poziom fluencji słownej przy różnych uszkodzeniach mózgu, „Studia Psychologiczne", t. 30, nr 1-2, s. 89-98. 
Marczinski C.A., Kertesz A., 2006, Category and letter fluency in semantic dementia, primary progressive aphasia, and Alzheimer's disease, „Brain and Language”, no. 97, s. 258-265.

Mattis S., 1988, Dementia Rating Scale professional manual, Florida: Psychological Assessment Resources.

Mayr U., 2002, On the dissociation between clustering and switching in verbal fluency: comment on Troyer, Moscovitch, Winocur, Alexander and Stuss, „Neuropsychologia”, no. 40, s. 562-566.

Moritz S., Birkner C., Jahn H., Hand I., Haasen C., Krausz M., 2002, Executive functioning in obsessive-compulsive disorder, unipolar depression, and schizophrenia, „Archives of Clinical Neuropsychology", vol. 17, issue 5, s. 477-483.

Mosiołek A., 2014, Metody badań funkcji poznawczych, „Psychiatria”, nr 11(4), s. 215-221.

Nęcka E., Orzechowski J., Szymura B., 2007, Psychologia poznawcza, Warszawa: Academica Wydawnictwo SWPS, Wydawnictwo Naukowe PWN.

Olszewski H., 2008, Otępienie czołowo-skroniowe. Ujęcie neuropsychologiczne, Kraków: Oficyna Wydawnicza „Impuls”.

Opala G.M., 2003, Epidemiologia otępień w perspektywie prognoz demograficznych, [w:] J. Leszek (red.), Choroby otępienne. Teoria i praktyka, Wrocław: Wydawnictwo Continuo, s. 19-26.

Parnowski T., 1998, Obraz kliniczny choroby Alzheimera, [w:] J. Leszek (red.), Choroby otępienne. Teoria i praktyka, Wrocław: Wydawnictwo Continuo, s. 47-69.

Parnowski T., 2010, Choroba Alzheimera, Warszawa: Wydawnictwo Lekarskie PZWL.

Pąchalska M., 2007, Neuropsychologia kliniczna. Urazy mózgu, Warszawa: Wydawnictwo Naukowe PWN.

Pąchalska M., MacQueen B.D., 1998, Bostoński Test Nazywania, Boston Naming Test (BNT). Autoryzowana wersja polska, Kraków: Fundacja na Rzecz Osób z Dysfunkcjami Mózgu.

Piskunowicz M., Bieliński M., Zgliński A., Borkowska A., 2013, Testy fluencji słownej - zastosowanie w diagnostyce neuropsychologicznej, „Psychiatria Polska”, t. XLVI, z. 3, s. $475-485$.

Podemski R., Słotwiński K., 2003, Zaburzenia mowy w procesach otępiennych, [w:] J. Leszek (red.), Choroby otępienne. Teoria i praktyka, Wrocław: Wydawnictwo Continuo, s. 271-283.

Ponichtera-Kasprzykowska M., Sobów T., 2014, Adaptacja i wykorzystanie testu fluencji słownej na świecie, „Psychiatria i Psychologia Kliniczna”, nr 14(3), s. 178-187.

Rende B., Ramsberger G., Miyake A., 2002, Commonalities and differences in the working memory components underlying letter and category fluency task: A dual task investigation, „Neuropsychology”, vol. 16(3), s. 309-321.

Robert P.H., Lafont V., Medecin I., Berthet L., Thauby S., Baudu C., Darcourt G., 1998, Clustering and switching strategies in verbal fluency task: Comparison between schizophrenics and healthy adults, „Journal of International Neuropsychological Society”, no. 4, s. 539-546.

Rosińczuk-Tonderys J., Murzyńska D., Kazimierska-Zając M., 2013, Porównanie fluencji słownej u kobiet ze starzeniem fizjologicznym i chorych z zespołami otępiennymi, „Forum Logopedyczne", nr 21, s. 88-93.

Ross T., 2003, The reliability of clusters and switch scores for the COWAT, „Archives of Clinical Neuropsychology", vol. 18, issue 2, s. 153-162.

Rossell S., 2006, Category fluency performance in patients with schizophrenia and bipolar disorder: the influence of affective categories, „Schizophrenia Research”, no. 82, s. 135-138.

Rutkiewicz-Hanczewska M., 2016, Neurobiologia nazywania. O anomii proprialnej i apelatywnej, Poznań: Wydawnictwo Naukowe Uniwersytetu Adama Mickiewicza.

Sellal F., Wolff V., Marescaux Ch., 2004, The cognitive pattern of vascular dementia and its assessment, „Seminars in Cerebrovascular Diseases and Stroke”, vol. 4(2), s. 79-86. 
Sitek E.J., Barczak A., Senderecka M., 2017, Zastosowanie jakościowej analizy profilu wykonania skali ACE-III w diagnostyce różnicowej chorób otępiennych, „Aktualności Neurologiczne”, nr 17(1), s. 34-41.

Stolarska U., Kroczka S., Gergont A., Steczkowska M., Kaciński M., 2008, Test fluencji słownej - aspekty rozwojowe w normie i patologii, „Przegląd Lekarski”, nr 65, s. 764-768.

Szatkowska I., Grabowska A., Szymańska O., 2000, Phonological and semantic fluencies are mediated by different regions of the prefrontal cortex, „Acta Neurobiologiae Experimentalis”, vol. 60, s. 503-508.

Szczepańska-Gieracha J., Greń G., Morga P., 2014, Zaburzenia językowe w chorobie Alzheimera, „Gerontologia Współczesna”, t. 2, nr 2, s. 73-75.

Szczudlik A., Parnowski T., 2012, Otępienie, [w:] M. Zabawa (red.), Diagnostyka i leczenie otępień. Rekomendacje zespołu ekspertów Polskiego Towarzystwa Alzheimerowskiego, Otwock: Medisfera, s. 1-8.

Szepietowska E.M., Daniluk B., 2000, Zaburzenia językowe w demencji w ujęciu neuropsychologii klinicznej, „Audiofonologia”, t. XVI, s. 117-135.

Szepietowska E.M., Gawda B., 2011, Ścieżkami fluencji werbalnej, Lublin: Wydawnictwo Uniwersytetu Marii Curie-Skłodowskiej.

Szepietowska E.M., Gawda B., 2012, Werbalna fluencja afektywna i narracje emocjonalne u osób z choroba Alzheimera i demencją naczyniowa, „Psychogeriatria Polska”, nr 9(1), s. 37-46.

Szepietowska E.M., Gawda B., 2013, Gramatyczne, semantyczne i afektywne cechy fluencji słownej: jakie czynniki determinuja ich wykonanie? Badania 302-osobowej grupy Polaków, „Psychologia - Etologia - Genetyka", nr 28, s. 47-66.

Szepietowska E.M., Gawda B., 2016, Mechanizmy neuronalne fluencji semantycznej i literowej: badania z użyciem fMRI. Implikacje kliniczne, „Polskie Forum Psychologiczne”, nr 21(2), s. $170-187$.

Szepietowska E.M., Lipian J., 2012, Fluencja słowna neutralna i afektywna u chorych z uszkodzeniem prawej, lewej lub obu pótkul mózgu, „Psychiatria Polska”, t. XLVI, nr 4, s. 539-551.

Troyer A.K., 2000, Normative Data for Clustering and Switching on Verbal Fluency Tasks, „Journal of Clinical and Experimental Neuropsychology", no. 22(3), s. 370-378.

Troyer A.K., Moscovitch M., Winocur G., Alexander M.P., Stuss D., 1998, Clustering and switching on verbal fluency: the effects of focal frontal and temporal-lobe lesions, „Neuropsychologia”, no. 36, s. 499-504.

Whatmough Ch., 2014, Otępienie, [w:] C.L. Armstrong, L. Morrow (red. wyd. pol. M. Harciarek), Neuropsychologia medyczna, Warszawa: Wydawnictwo Lekarskie PZWL, s. 3-33.

Wood A., Saling M., Abbott D.F., Jackson G.D., 2001, A neurocognitive account of frontal lobe involvement in orthographic lexical retrieval: an fMRI study, „Neuroimage”, vol. 14, issue 1, s. $162-169$.

Wysokiński A., Zboralski K., Orzechowska A., Gałecki P., Florkowski A., Talarowska M., 2010, Normalization of the Verbal Fluency Test on the basis of results for healthy subjects, patients with schizophrenia, patients with organic lesion of the chronic nervous system and patients with type 1 and 2 diabetes, „Archives of Medical Science”, vol. 6(3), s. 438-446.

Zawadzka E., 2013, Świat w obrazach u osób po udarze mózgu, Warszawa: Wydawnictwo Difin.

Żulewska J., 2015, Ocena przydatności testu do oceny fluencji słownej w diagnostyce zaburzeń funkcji językowych u pacjentów z uszkodzeniami prawej pótkuli mózgowej, [w:] M. Kurowska, E. Wolańska (red.), Metody i narzędzia diagnostyczne w logopedii, Warszawa: Dom Wydawniczy Elipsa, s. 109-124. 


\begin{tabular}{|l|l|}
\hline \multirow{2}{*}{ CC } & $\begin{array}{l}\text { (c) by the author, licensee Łódź University - Łódź University Press, tódź, Poland. } \\
\text { This article is an open access article distributed under the terms and conditions } \\
\text { of the Creative Commons Attribution license CC-BY-NC-ND } 4.0 \\
\text { (https://creativecommons.org/licenses/by-nc-nd/4.0/) }\end{array}$ \\
\cline { 2 - 2 } & Data złożenia: 21.03.2021. Data przyjęcia: 09.05.2021. \\
\hline
\end{tabular}

